
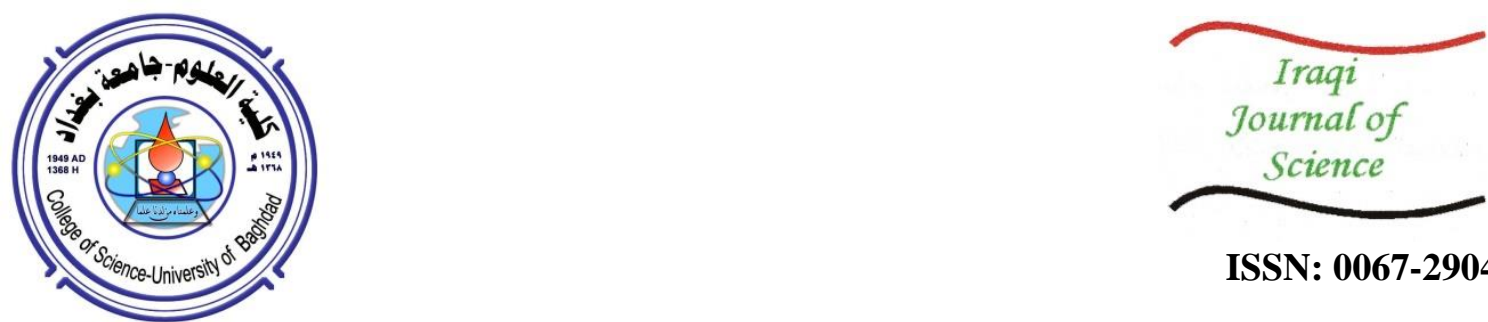

ISSN: 0067-2904

\title{
The Use of Seismic Reflection Data Inversion Technique to Evaluate the Petro- Physical Properties of Nahr Umr Formation at Kumait and Dujaila Oil Fields - Southern Iraq
}

\author{
Nowfal A. Nassir ${ }^{1}$, Ahmed S. AL- Banna*11, Ghazi H. Al-Sharaa ${ }^{2}$ \\ ${ }^{1}$ Department of Geology, College of Science, University of Baghdad, Baghdad, Iraq \\ ${ }^{2}$ Oil Exploration Company, Iraq
}

Received: 20/5/2020

Accepted: 13/8/2020

\begin{abstract}
The estimation of rock petrophysical parameters is an essential matter to characterize any reservoir. This research deals with the evaluation of effective porosity $(\mathrm{Pe})$, shale volume (Vsh) and water saturation $(\mathrm{Sw})$ of reservoirs at Kumait and Dujalia fields, which were analyzed from well $\log$ and seismic data. The absolute acoustic impedance (AI) and relative acoustic impedance (RAI) were derived from a model which is based on the inversion of seismic 3-D post-stack data. NahrUmr formation's sand reservoirs are identified by the RAI section of the study area. Nahr Umr sand-2 unit in Kumait field is the main reservoir; its delineation depends on the available well logs and AI sections information. The results of well logging interpretation showed a decrease of $\mathrm{Sw}$ and Vsh and an increase of effective porosity in the oil reservoir area, which coincides with the decrease of AI values. The existence of the water reservoir in Du-2 well revealed a convergence of the results of AI and effective porosity with those of Kumait wells, along with and some differential results of $\mathrm{Sw}$ and Vsh values that may be related to changes in lithology and fluid density.
\end{abstract}

Keywords: Nahr Umr Formation, Acoustic Impedance, Water Saturation, Shale Volume, Kumait oil field, Iraq.

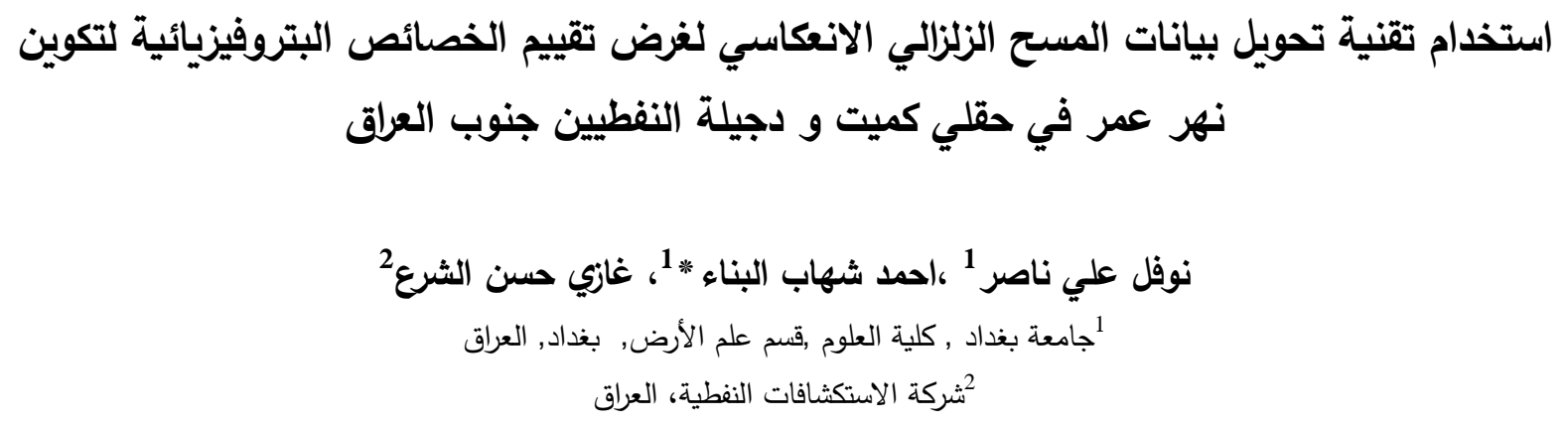

$$
\begin{aligned}
& \text { الخلاصه } \\
& \text { تم مقارنة قيم المعلومات البتروفيزيائية مع قيم المعكوس الزلزالي لأبار كميت-1و2 ودجيلة-2 حيث تم } \\
& \text { تقييم المسامية الفعالة وحجم تواجد الثيل والتشبع المائي لمكامن حقلي كميت والدجيلة النفطيين من سجلات } \\
& \text { الابار والبيانات السيزمية حيث لوحظ انخفاض في قيم الممانعة الصوتية النسبية (RAI) من البيانات الزلازلية }
\end{aligned}
$$

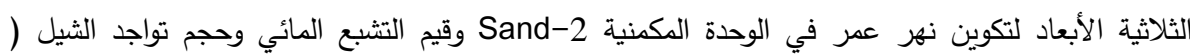

$$
\begin{aligned}
& \text { وبعh ولزض الزيادة في نسبة المسامية الفعالة في منطقة المكمن النفطي ، كما اظهرت بئر دجيلة-2 تقارب }
\end{aligned}
$$




$$
\begin{aligned}
& \text { في قيم الممانعة الصوتية Al والمسامية الغعالة في المكمن المائي مع نتائج أبار حقل كميت و اظهرت بعض }
\end{aligned}
$$

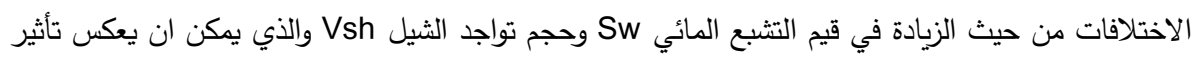

$$
\begin{aligned}
& \text { التغير في الصخارية او في كثافة السوائل. }
\end{aligned}
$$

\section{Introduction}

The detection of petrophysical properties, including Pe, Vsh, water saturation ( $\mathrm{Sw}$ ), and reservoir volume, size and thickness, has a key role in oil and gas industry $[1,2]$. Spatial variation of petrophysical properties can be identified by using the well logging and seismic data which are available to characterize the reservoir. Conversion of AI to any of the petrophysical parameters in the homogenous medium may provide a reliable indication for the petrophysical properties in the seismic portion. The inversion technique is concerned with evaluating the quality of the various parts of the formation and separating the reservoir as an isolated unit in order to determine the most promising depths to improve the exploitation of the reservoir and to develop the oil fields. This may be achieved by evaluating the petrophysical properties and interpreting data obtained from well logging. Lithology, $(\mathrm{Vsh})$, total porosity $(\mathrm{Pt})$, effective porosity $(\mathrm{Pe})$ and $(\mathrm{Sw})$ are the most relevant parameters in the petrophysical analysis to evaluate the quality of the reservoir formation [3]. According to experts from exploration and production companies, hydrocarbon reservoirs consist of two separate phases of liquids, namely the water-gas and oil-water. Most of the reservoirs have all the three phases of gas, oil, and water [4]. Sandstone is the most famous type of rock reservoir, which seems to have plenty of void to reserve hydrocarbons $[5,6]$. The goal of the proposed study is to interpret well logging data and evaluate quantitatively the petrophysical properties, such as effective porosity, volume of shale (Vsh) and water saturation (Sw), in the study area. Sand-2 unit in Nahr Umr Formation is the main reservoir in Kumait field and presence water reservoir in Dujalia field. Using well log and 3D poststack seismic data, the research included determining the sand reservoirs from Nahr Umr Formation in the Middle Cretaceous period. We concentrate on log interpretation for assessing effective porosity, volume of shale, and water saturation, while linking the synthetic model to surface seismic data, absolute acoustic impedance (AI) inversion, and relative acoustic impedance (RAI). The petrophysical parameters from inversion to reservoir delineation included those of the oil reservoir, or water reservoir, and AI inversion from sections in the study area.

\section{Location of Study the Area}

Kumait and Dujalia Oil Fields are located in Missan city and northeast of Nasiriyah City, southeastern Iraq, as shown in Figure-1. There are four wells (Kt-1,2 and Du-1,2) that penetrate Nahr Umr Formation in Kumait and Dujalia Oil Fields, within the Universal Transverse Markator (U.T.M) coordinates, as given in Table -1 .

Table 1- Coordinates of the study area.

\begin{tabular}{|c||c|c|}
\hline Point & Northern & Eastern \\
\hline A & 3560000 & 620000 \\
\hline \hline B & 3560000 & 682000 \\
\hline \hline C & 3520000 & 682000 \\
\hline \hline D & 3520000 & 620000 \\
\hline
\end{tabular}




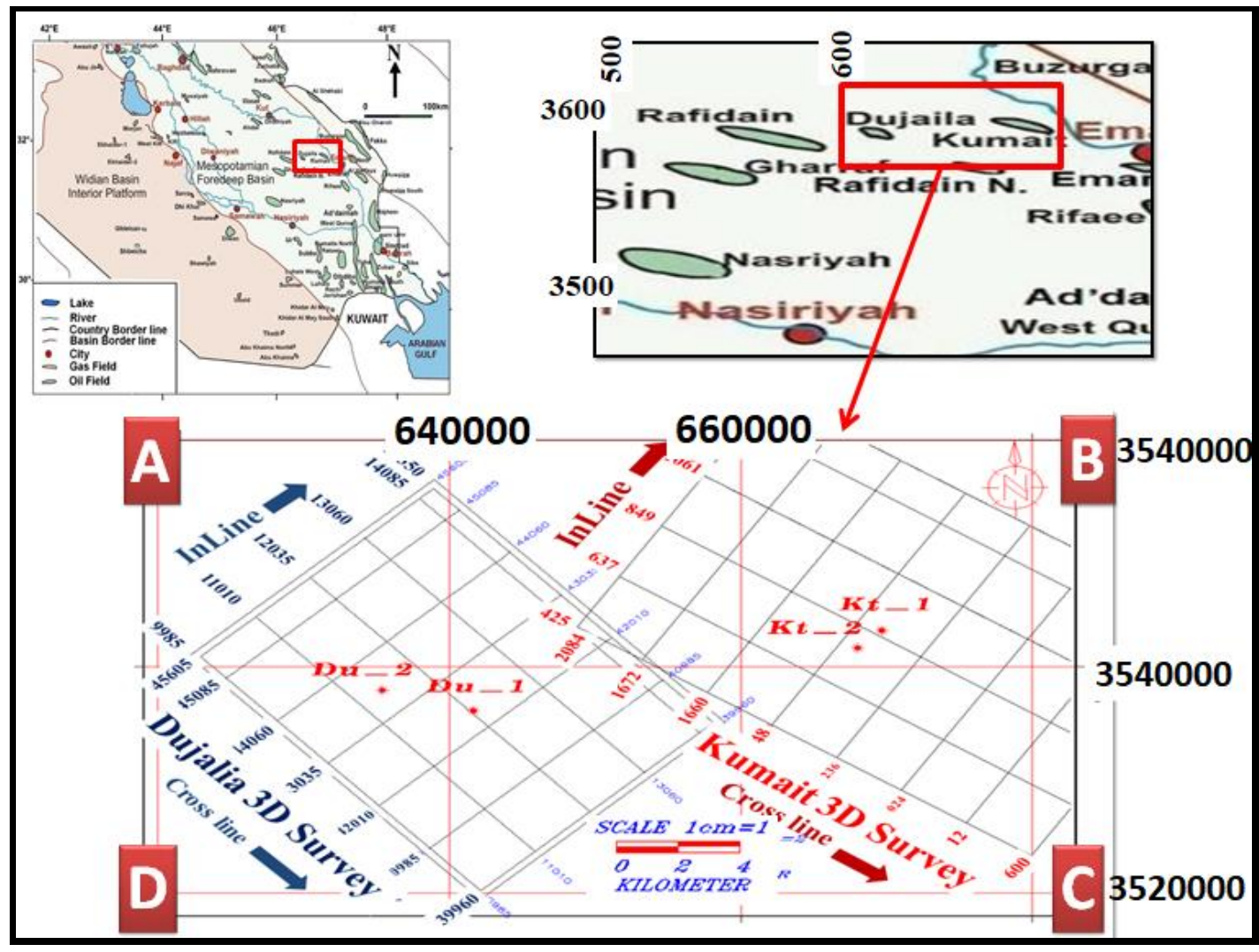

Figure 1- Location and base map of the study area, after [5,6,7].

\section{Subsurface Geology}

\subsection{Nahr Umr Formation in Kumait field}

The well Kumait-1 is located within the depth range of 3700 and 3838.5 m., while the well Kumait2 is located within the depth area of $3707-3857 \mathrm{~m}$. From the examination of the reservoir, it was possible to distinguish sand units separated by cover layers of nonporous shale rocks, as demonstrated in Figure -2. Three sand units were recognized in the wells Kt-1 and Kt-2, which is described below.

\section{a- First Sand Unit SAND1}

The well Kt-1 shows this unit at a depth range of 3793 - 3795 m, while the well Kt- 2 lies within a depth range of 3810 - $3817 \mathrm{~m}$ and consists of porous sand. Sandstone porosity values range between 0 and $38.5 \%$ with values of $22 \%$ and $22.2 \%$, respectively, in the two wells of Kt-1 and Kt-2 [5]

\section{b- Second Sand Unit SAND2}

The well Kt-1 shows this unit which is found within a depth range between 3804 and $3815 \mathrm{~m}$, while Kt- 2 well appears within a depth range between 3823.5 and $3829.5 \mathrm{~m}$. These units are composed of porous sand rocks with porosity ranges of $20-28.5 \%$ and $17-22.5 \%$ at the two wells of Kt-1 and Kt-2, respectively [5].

The production of this unit was tested in the well $\mathrm{Kt}-1$, where the oil proved to be present The results of well evaluation which were obtained by using Computer Processing Interpretation (CPI) indicated that the unit contains water in the well Kt-2.

\section{c- Third Sand Unit SAND3}

The well Kt-1 lies within a depth range of 3822.5 - $3840 \mathrm{~m}$, while the well Kt-2 is located at a depth range of 3831- 5 - $3854 \mathrm{~m}$. It consists of porous sand with porosity values ranging between 12$25 \%$ and $14-35 \%$ for the two wells, respectively [5].

The results of well evaluation by using CPI indicated that the unit contains water in the two wells.

\subsection{Nahr Umr Formation in Dujaila field}

Nahr Umar Formation rocks are found in the well $\mathrm{Du}-2$ which is located within a depth range between 3471 and $3610 \mathrm{~m}$. As related to the reservoir, it was possible to distinguish sand units separated by covers of layers of nonporous shale rock and limestone. The logs data are not available in Dujalia -1 well (Figure-3) [6]. 


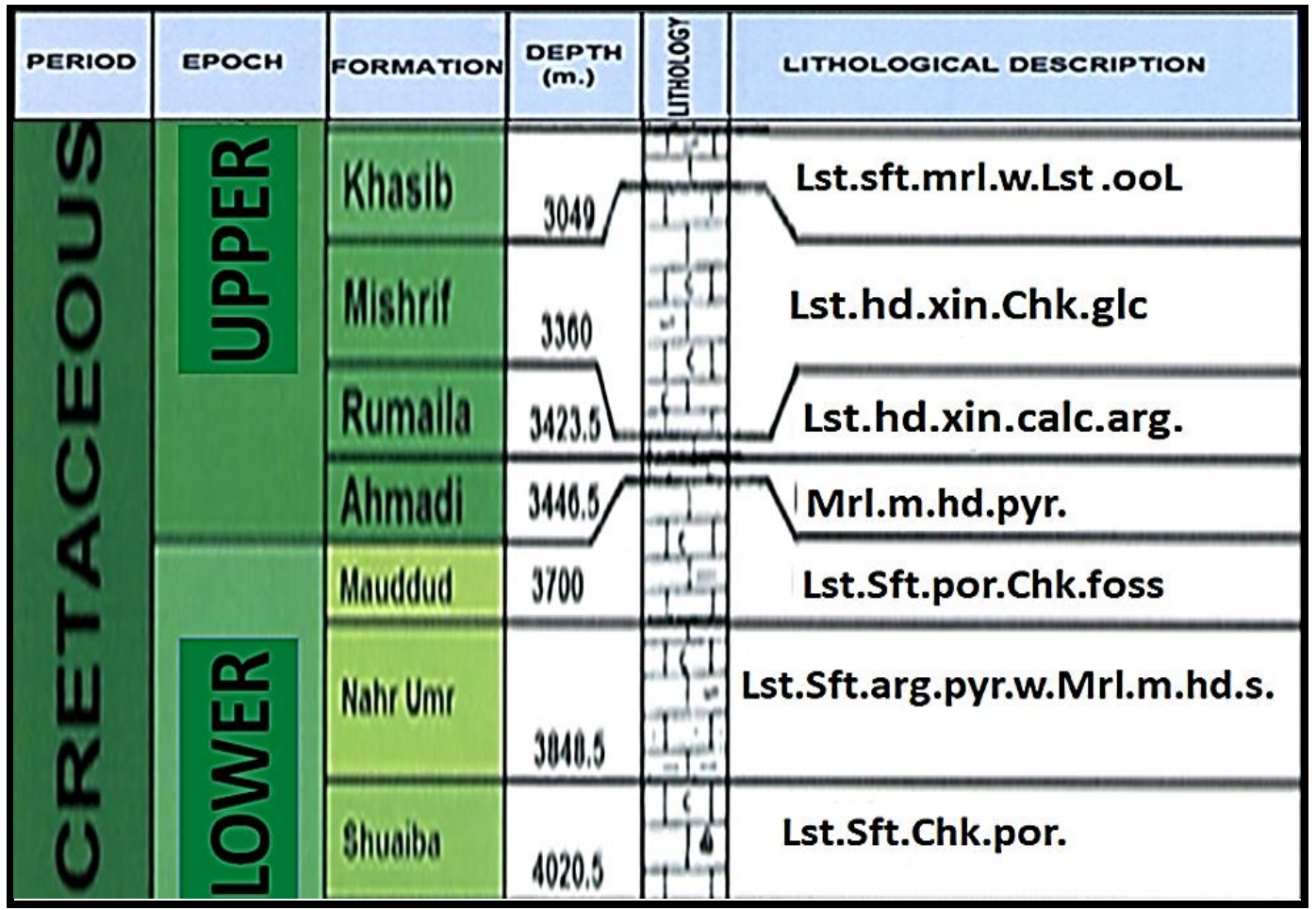

Figure 2- Geological column in Kt-1 well, after [5].

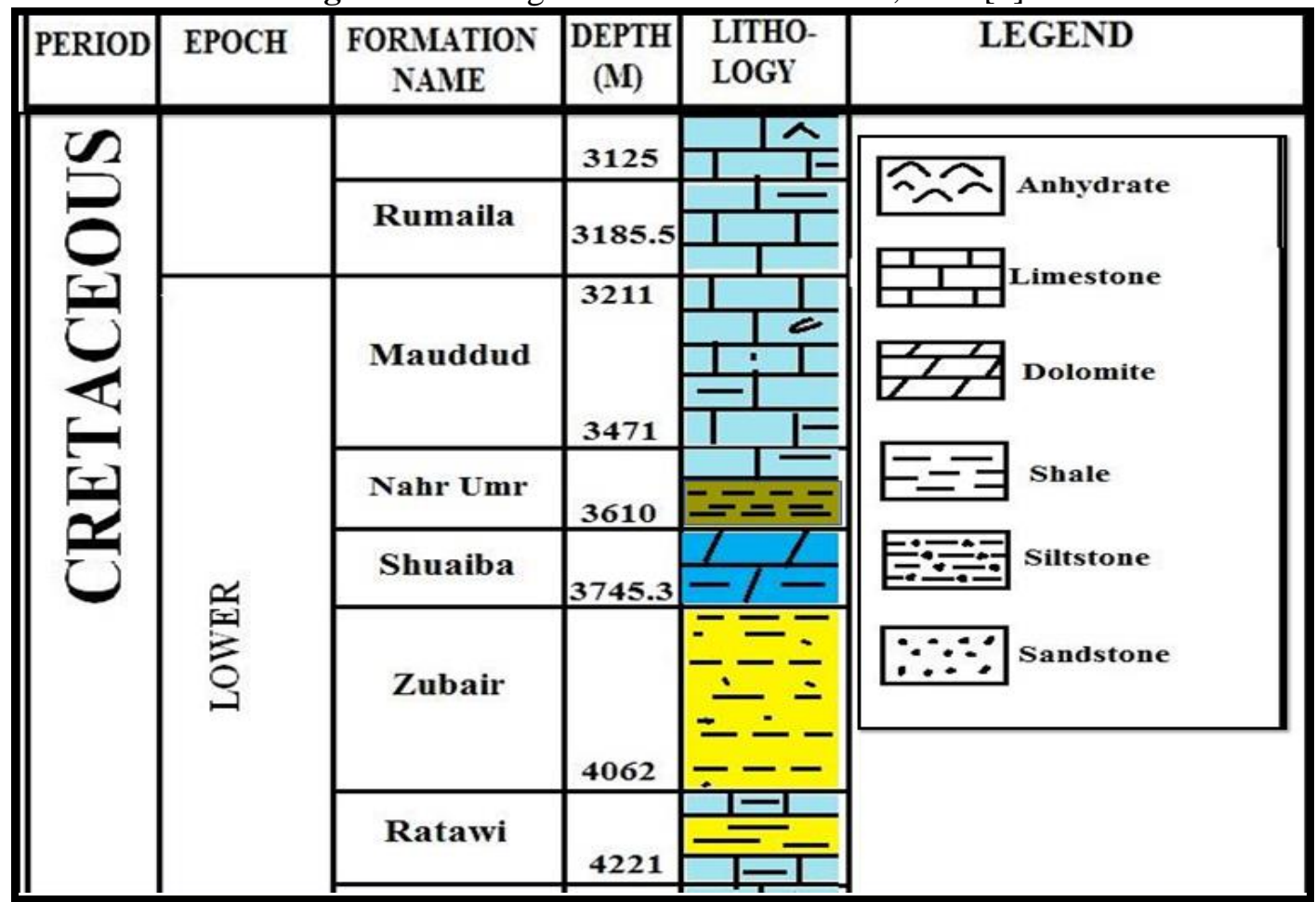

Figure 3- Geological column in Du-2 well, after [6].

4. The regional tectonic situation of the study area

The Iraq tectonic map shows that the area is located at the central part of the Mesopotamian basin near the north-eastern slope of the Arabian-African platform; it is located between Zagros Faulting zone at the east and the Arabian Shield at the west [8,9]. The general faulting trends are in the direction NW-SE, due to the stresses of tectonic movements. A group of small fold closures appear in the region, such as those found in Dujaila, Abu Amoud, East Abu Amoud and Kumait fields. The trend of structure axes of Dujaila and Kumait agrees with the adjacent structure axes [10, 11]. Kumait and Dujaila fields are located within the Euphrates structural subzone in the area that does not show 
any structural features [12]. The Mesopotamian basin shows many subzones from north to south , which are Tikrit-Amara, Samawa-Nasiriya, and Zubair subzones [12]. Some parts of the study area are located in Tikrit-Amara subzone, whereas other parts are located in Samawa- Nasiriya subzone $[12,13]$.

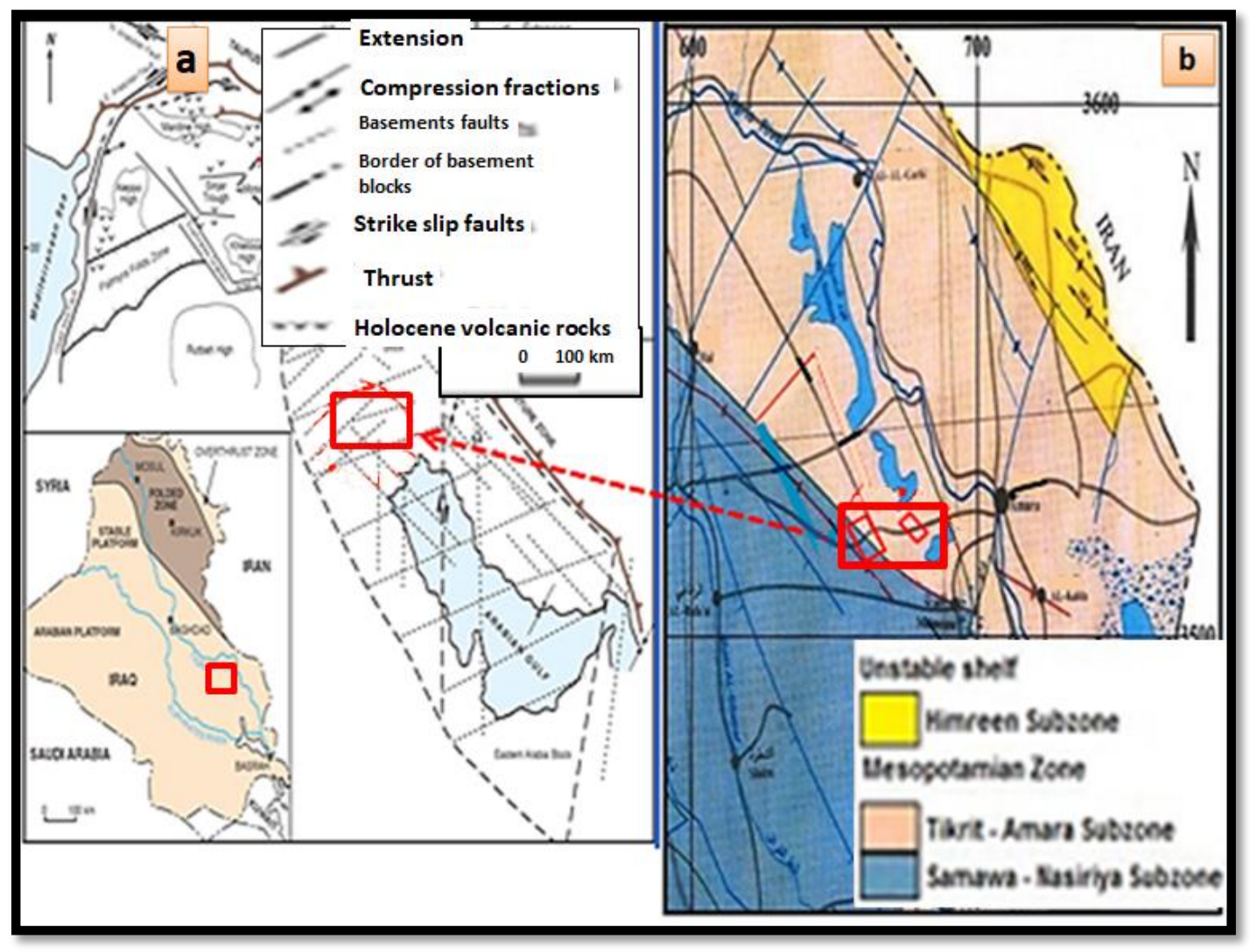

Figure 4 (a)-Tectonic elements and basement fault trends for the NE Arabian Plate [7] with an inset map that shows the tectonic zones of Iraq. (b) Tectonic map of the study area, after [8].

\section{Post-Stack Seismic Resolution Inversion}

Few reflection coefficients with higher amplitudes were distinguished by the Post-Stack seismic resolution inversion technique. The inversion results are presented as Acoustic Impedance (AI) which was calculated from rock density and p-wave velocity. AI is a rock property that could be derived from seismic reflection data, which is also considered as an interface property. At every trace, seismic data can be transformed to an acoustic impedance log. Acoustic impedance is used to make more accurate and acoustic structural and stratigraphic measurements. It is also associated to many geological environments and has a strong relationship to petro-physical properties such as porosity and type of lithology. Interpretations of seismic attributes and petroleum properties, including porosity, lithology and fluid saturation are strongly related to seismic acoustic impedance. In many geological settings, seismic inversion results may be used in seismic reservoir characterization studies to provide a spatial distribution of the properties of lithology, petro-physics and reservoirs. This will provide information that could be used directly to quantify hydrocarbons. The data integration process is performed at first by achieving a rock physical study by using well information in order to evaluate the ability of seismic-derived acoustic and elastic properties to discriminate the lithology and fluid content of the reservoir. The integration processor uses inversion and petro-physical information to build a bridge between the two domains. The conditional probability of predicting reservoir distributions and petro-physical properties is essential in characterizing any reliable seismic reservoir [14].

\section{Shale Volume (Vshale)}

Vshale is the volume of shale within a given rock volume. It is typically synonymous with clay, but it should be calculated specifically on a different scale; $V_{\text {clay }}$ pertains to a rock, whereas $V_{\text {sh }}$ pertains to an interval of strata. The technique that uses geological observations and information to estimate the original fluids in place is the volumetric analysis technique. As it primarily sources its data from core 
samples, the static method is generally referred to as wireline logs. Usually, volumetric calculations use prior production to estimate reserves, and after a considerable production, the recovery efficiency of the reservoir areal extent is identified and used as the basis for advanced studies such as reservoir simulations [15].

\subsection{Calculation of the Shale Volume}

Larionov 1969 [16] suggested two formulas to measure shale volume by using gamma ray log.

The first formula is for recent rocks and expressed as follows:

$$
\mathrm{Vsh}=0.083(23.7 * 1 \mathrm{GR}-1)
$$

The second formula is for older rocks and expressed as follows:

$$
\mathrm{Vsh}=0.33(22 * 1 \mathrm{GR}-1)
$$

$\mathrm{IGR}=\frac{\text { GRlog-GR } \min }{\text { GRmax }- \text { GRmin }}$

where Vsh is the shale volume, IGR is the gamma ray index, , GRlog is the gamma ray reading, GRmax is the maximum gamma ray reading, and GRmin is the minimum gamma ray reading. Computation of shale volume is necessary because it is useful in calculating water saturation. If the reservoir has shale within its body (shaly), like that with delta, the reservoir will have greater saturation of water. This is based on the ability of the shale to absorb water, which will increase water saturation. Low permeability could be an indication of whether the zone is of interest or not upon estimating shale volume. Many users will not usually classify a high shale volume formation as a reservoir [17].

Nahr Umr Formation appears in a blue-purple color as distinguished in the seismic section (Figure5). It is composed of compacted limestone. The behavior of the Vsh log in this layer showed an increase in the shale ratio.

Sand-1 unit appears in red and green colors in the seismic inversion section, as shown in Figure-5, which represent a shale. A change of the curve behavior was noticed for the Vsh log near this layer, where a high drop is present, due to the fact that the shale reduces hydrocarbon accumulation.

Sand-2 (reservoir unit) is shown in a brown color in the seismic inversion section. It was noticed that the behavior of the Vsh log curve near this layer shows a slight drop, which is due to the presence of shale and the increase of sand with relatively low acoustic impedance. This confirms a clean reservoir unit that contains high accumulation of hydrocarbon, as shown in Figure-5.

Sand-3 appears in green yellow color in the seismic inversion section. The behavior of the Vsh log curve in this layer showed a slight increase in the shale to sand ratio.

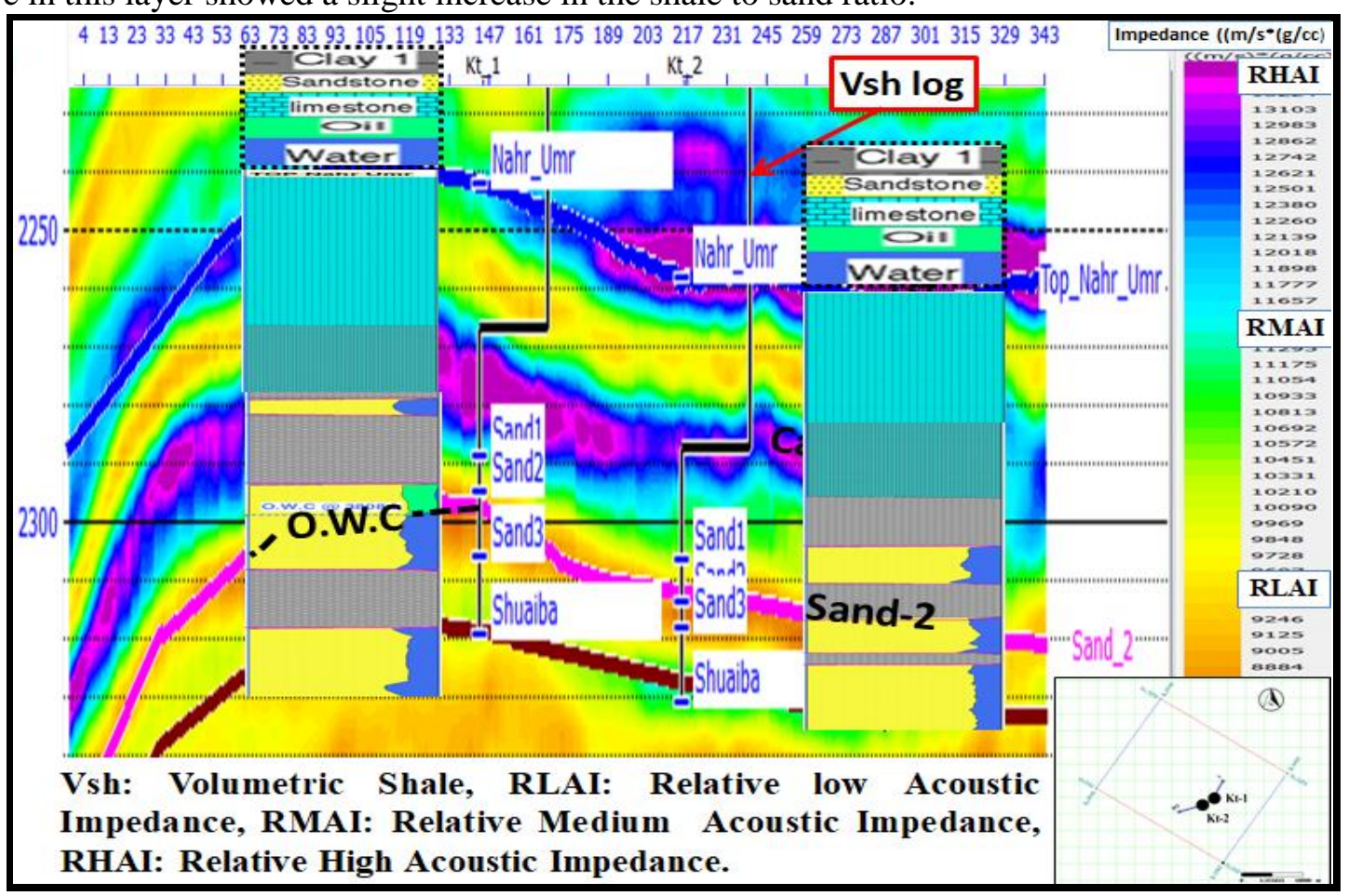

Figure 5- Arbitrary section of inverted Relative Acoustic Impedance (RAI) with volumetric shale logs in Nahr Umr Formation passing through the wells Kt_1and Kt_2. 
The color data in the seismic inversion section show an acoustic impedance value only around the well Du-2, while well data of Du-1 is not available, as shown in Figure-6. The existence of sandstoneshale in the stratigraphic column of Nahr Umr Formation refers to a relatively low acoustic impedance, as shown in Figure-6. It could be recognized as green color in the seismic section. Also, an increase was observed in the volumetric shale ratio. A low water content was proved in the sandy shale bed in this formation, as detected by CPI and shown in the arbitrary section of inversion in Figure-6. The acoustic impedance might vary laterally due to porosity variation or changes in reservoir quality. Such changes may be interpretable in terms of rock property variation.

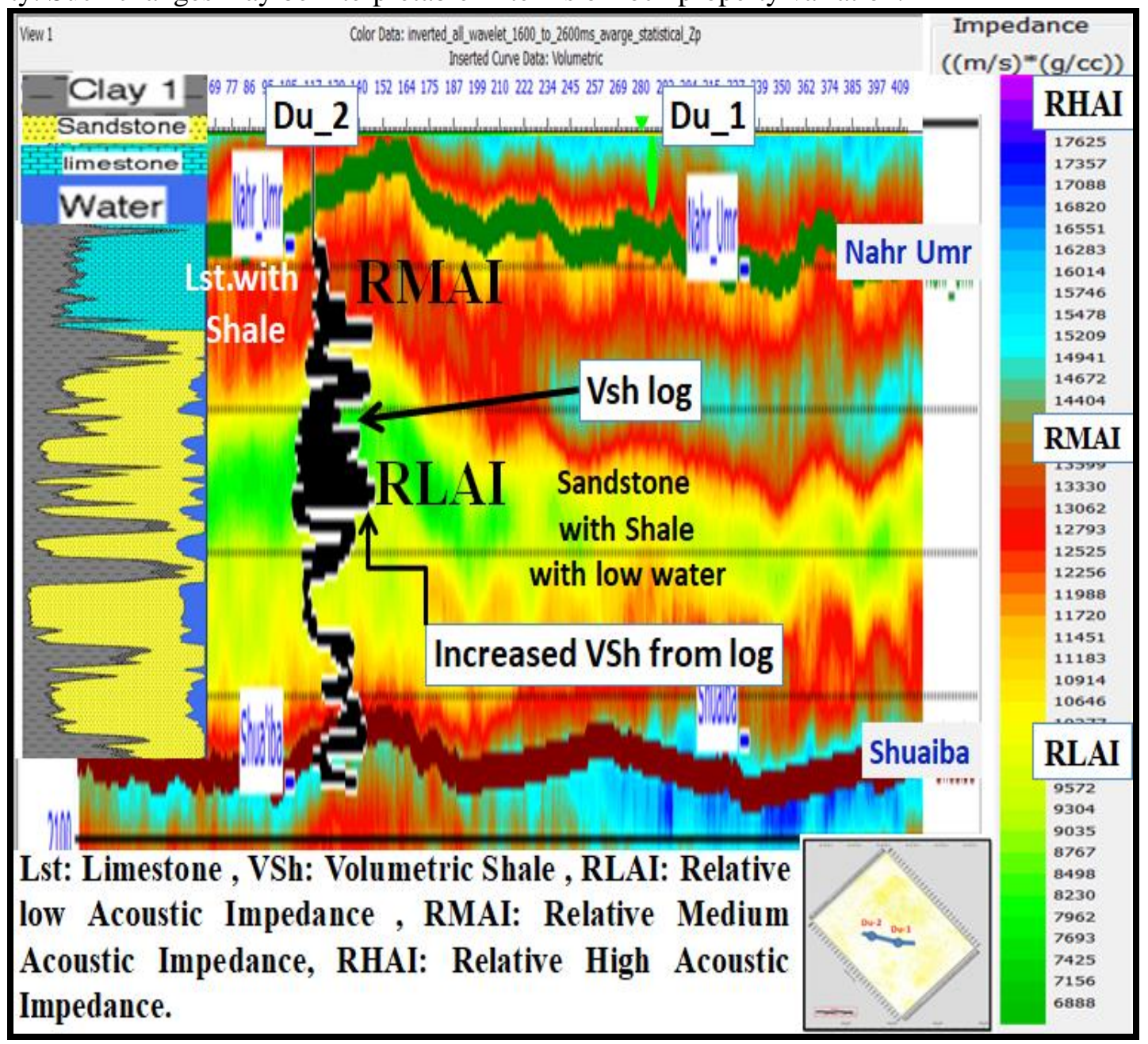

Figure 6- Arbitrary section of inverted Relative Acoustic Impedance (RAI) with volumetric shale logs in Nahr Umr Formation passing through wells Du_1and Du_2.

\section{Water saturation parameter}

The volume values of water and pores are important in calculating water saturation. Water bound to the shale is not included, while water saturation $(\mathrm{Sw})$ is calculated from the resistivity and effective porosity logging data. Water saturation of a reservoir is a function of height above free water and the form of pore. The height $(\mathrm{h})$, radius of pores $(\mathrm{r})$, and pore throat size distribution in the reservoir should be taken into consideration when interpreting Sw property. Archie is the most widely used equation to calculate hydrocarbon saturation, as follows:

Hydrocarbon saturation $(\mathrm{Sh})=1-\mathrm{Sw}$

The use of water or hydrocarbon saturation is an important petrophysical parameter to evaluate the oil and gas reservoirs. In order to determine water saturation from well logs, there are many relationships which depend on the physical properties of rocks. The exact determination of hydrocarbon formation or water saturation depends on the precision of the measured parameters and the relationships used. Hamada [18] defined the evaluation of water and hydrocarbon saturation as one 
of the main goals of well logging [19]. All reservoirs of oil and gas are water-wet; water coats the surface of every grain of rock. Several reservoirs are oil-wet, with oil in the pores is surrounded by oil on the rock surface, and water. Some of these reservoirs are partly oil-wet. Oil-wet reservoirs are very low producers, because it is extremely difficult to separate oil from the rock surface. It is relatively easy to take a core sample, clean and dry it, then make the rock-wet oil. Reservoir rocks, nevertheless, are never clean and dry and, hence, the same in-situ rock is predominantly water-wet [16].

Sand-2 unit showed a decrease in water to oil saturation ratio during log interpretation. Around the Kt-1 well, oil-water contact could be distinguished, particularly at the sand-2 unit, by the increase in $\mathrm{Sw}$ ratio and AI value, as shown in Figure-7.

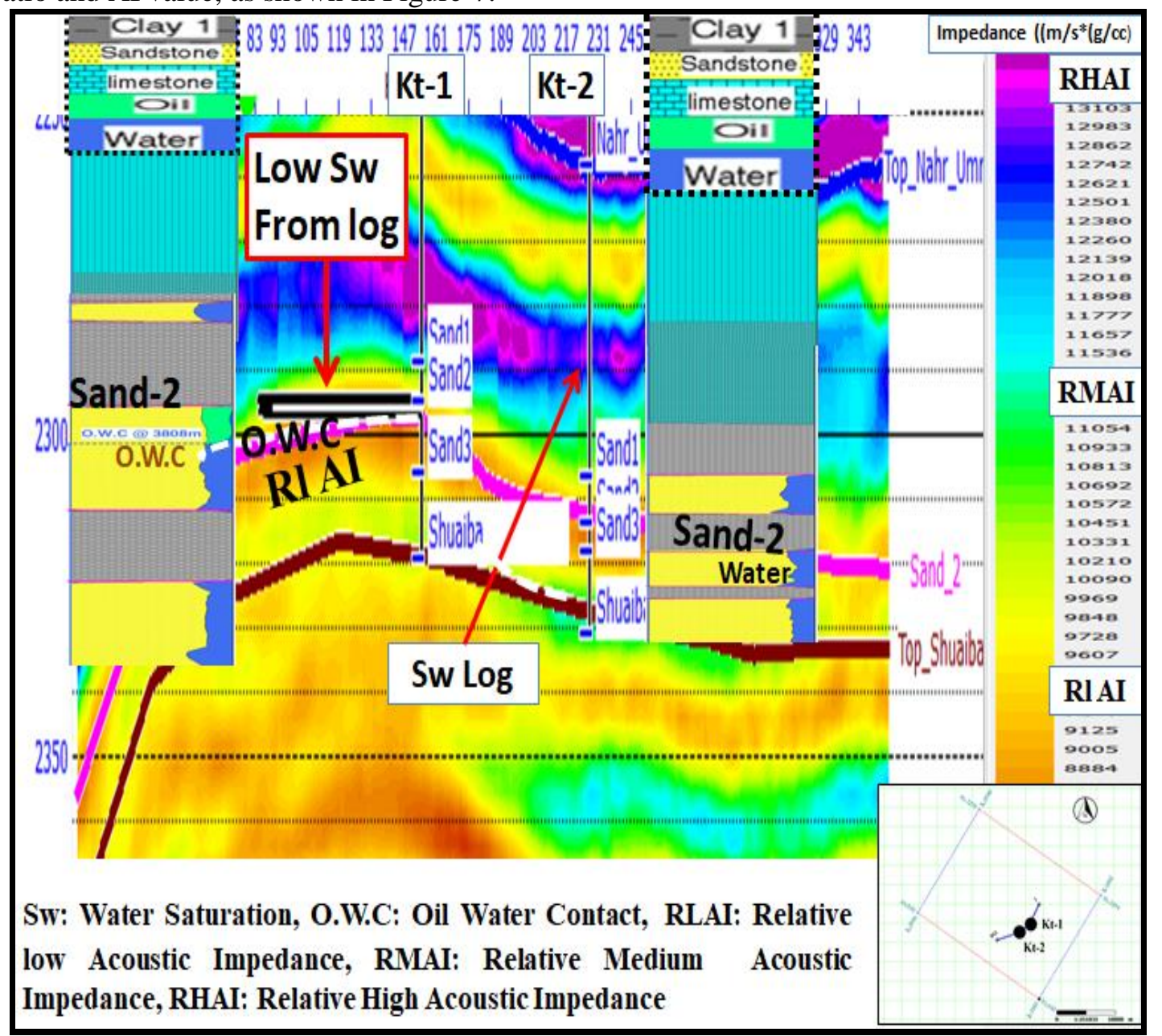

Figure 7- Arbitrary section of inverted Relative Acoustic Impedance (RAI) with Sw logs in Nahr Umr Formation passing through wells Kt_1and Kt_2.

By observing Figure-8, it could be observed that Dujalia oil field showed a relatively low acoustic impedance value around the well of Du-2 at Nahr Umr Formation. The low acoustic impedance value can be distinguished near the sandy-shale layer with increasing $\mathrm{Sw}$ ratio, which is higher than that of limestone-shale layer at the upper part of Nahr Umr Formation. The changes of color indicate the difference in acoustic impedance value of seismic inversion section. The values of water saturation in Du-2 well within Nahr Umr Formation, as obtained by CPI logs, are shown in the arbitrary section of inversion (Figure-8). 


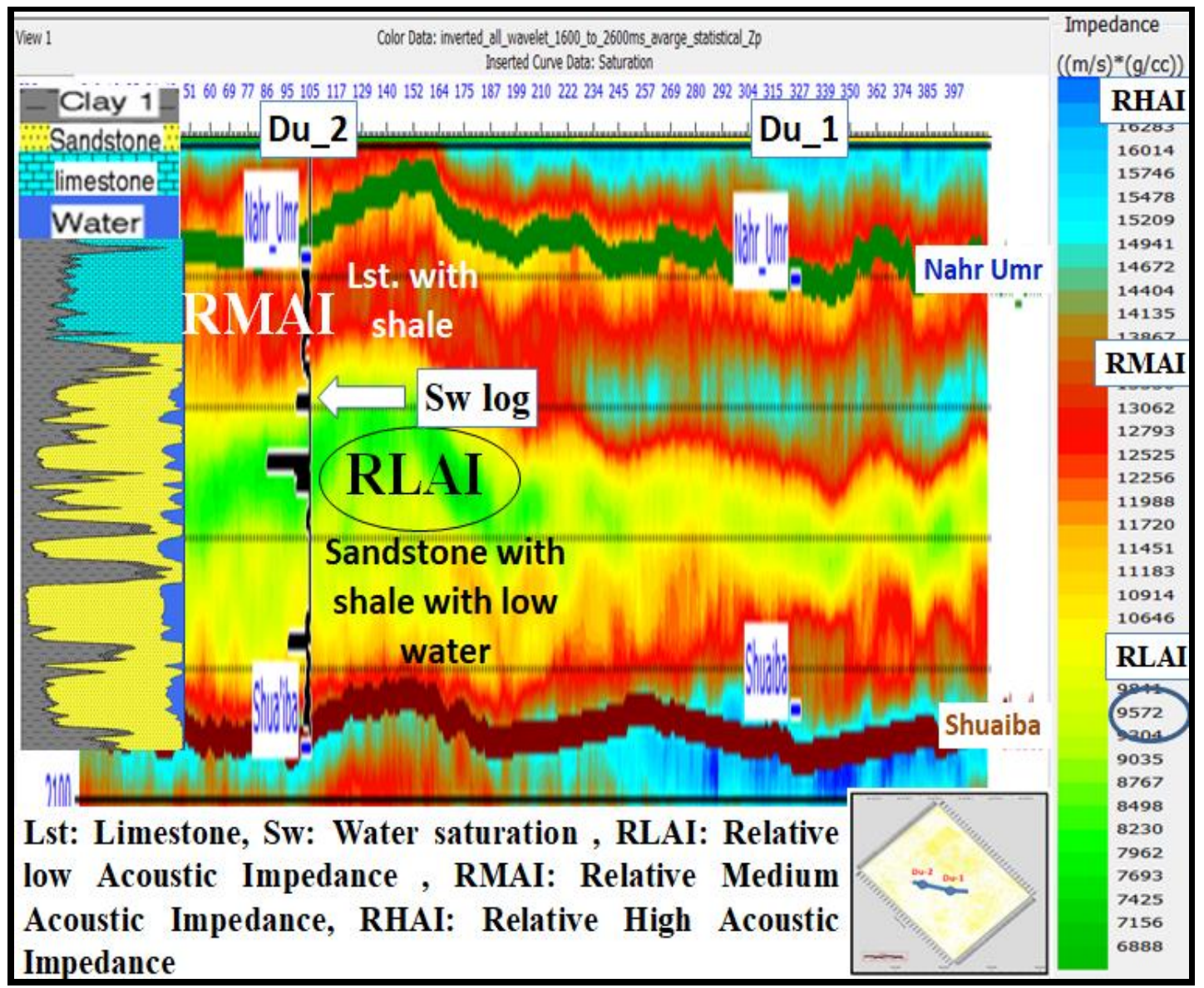

Figure 8- Arbitrary section of inverted Relative Acoustic Impedance (RAI) with Sw logs in Nahr Umr Formation passing through wells $\mathrm{Du} \_1$ and $\mathrm{Du} \_$.

\section{Effective porosity}

Effective porosity is that portion of a porous material's total void space that transmits fluid. Total porosity is the ratio of total volume of void to total bulk volume of rock.

One indicator of the ability to absorb or store fluids is the porosity of a rock. Porosity is measured as the porous volume of the rock divided by its bulk volume.

$$
\text { Porosity }(\varnothing)=\frac{\text { Pore Volume }}{\text { Bulk Volume }}
$$

Expressed in terms of symbols, Eq. (4) is represented as:

$$
\varnothing=\frac{\mathrm{V}_{\mathrm{P}}}{\mathrm{V}_{\mathrm{B}}}
$$

In Eq. $5, \emptyset=$ porosity; $\mathrm{V}_{\mathrm{p}}=$ pore volume; and $\mathrm{V}_{\mathrm{B}}=$ bulk volume. Pore volume is the total volume of pore spaces in the rock, while bulk volume is the physical volume of the rock, which includes the pore spaces and matrix materials (sand and shale, etc.) that compose the rock [2]. Types of pores in the rocks represent primary porosity and secondary porosity. Primary porosity is defined as the porosity of a rock that is formed during the time of its deposition. Secondary porosity forms during rock deposition. Secondary porosity includes vugular spaces produced by the chemical leaching process in carbonate rocks, or fracture spaces formed in fractured reservoirs. Porosity is also categorized as total porosity and effective porosity. Total porosity is known as the ratio of the total pore space in a rock to its bulk volume. Effective porosity is the total porosity except for the fraction of the pore space occupied by shale or clay. Total porosity is equal to effective porosity in very clean sands. Figure- 9 illustrates the effective porosity which reflects pore space that contains hydrocarbon and non-clay water. A precise definition of effective porosity is total porosity minus volume of clay-bound water [2]. For a shaly sand model, the relationship between total porosity and effective porosity can be represented as:

$$
\emptyset_{t}=\emptyset e+V_{s h} * \emptyset_{s h}
$$




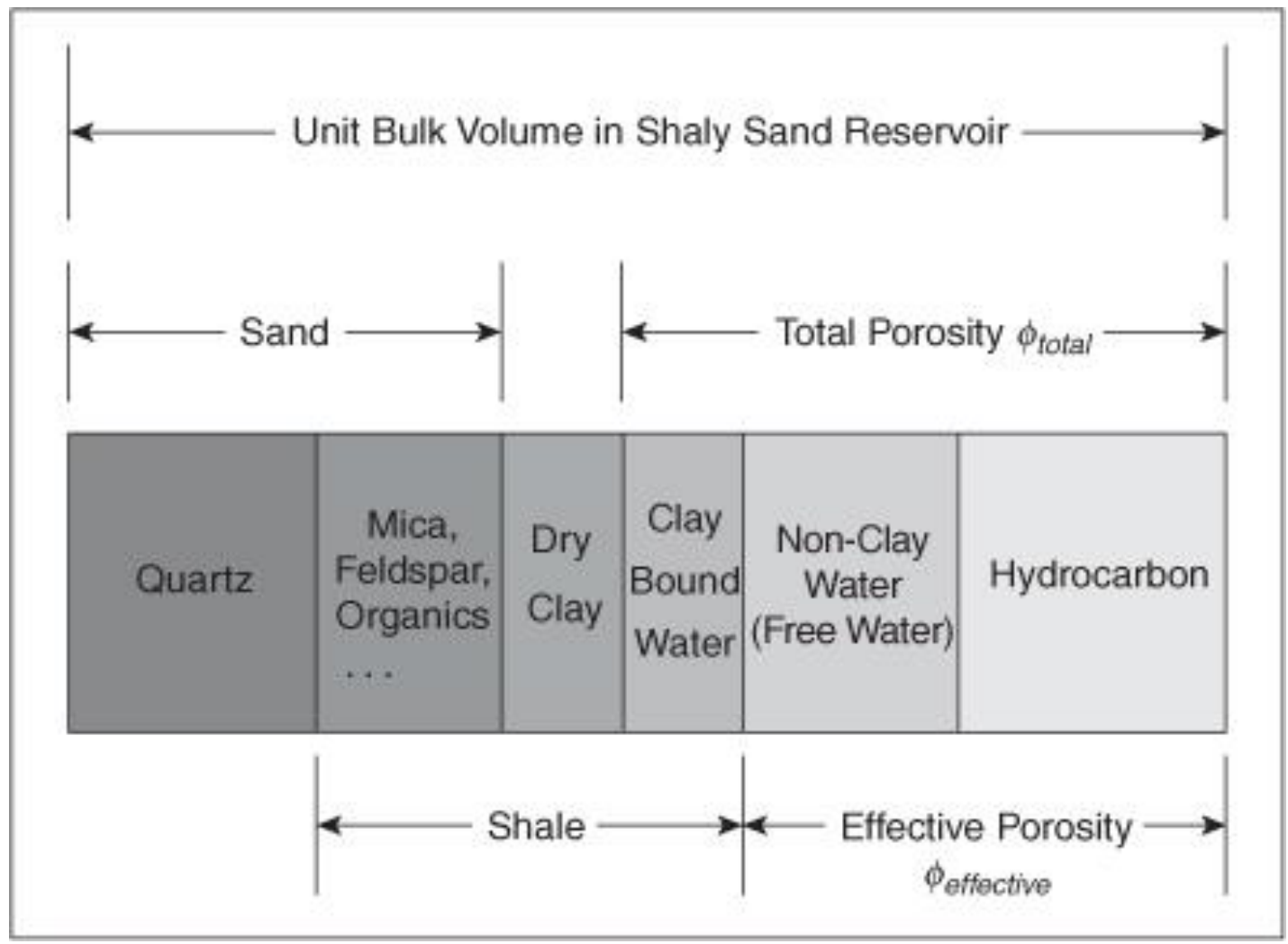

Figure 9- The porosity model for a shaly sand reservoir, after [20].

In Eq. $6, \emptyset_{\mathrm{t}}=$ total porosity, fraction; $\emptyset_{\mathrm{e}}=$ effective porosity, fraction; $\mathrm{V}_{\mathrm{sh}}=$ volume of shale, fraction; and $\emptyset_{\mathrm{sh}}=$ shale porosity, fraction. It is often difficult and inaccurate to determine shale porosity from well logs because the selection of the $100 \%$ shale section may be incorrect and subjective. For this reason, an approximate form of Eq. 6 is obtained by replacing shale porosity $\emptyset_{\text {sh }}$ with total porosity $\emptyset_{\mathrm{t}}$ to get:

$$
\emptyset_{t}=\emptyset_{e}+V_{s h} * \emptyset_{t}
$$

Effective porosity for a clay model is represented by:

$$
\emptyset_{\mathrm{t}}=\emptyset_{\mathrm{e}}+\mathrm{V}_{\mathrm{cbw}}
$$

In Eq. 8, $\mathrm{V}_{\mathrm{cbw}}=$ volume of clay-bound water, fraction. For the calculation of correct effective porosity, the application of Eq. 8 depends on accurate quantification of the volume of clay-bound water. This can be determined from Elemental Capture Spectroscopy (ECS) well logs.

The sand-2 unit within Nahr Umr formation in Kt-1well shows an increase of porosity with a low density and relatively low acoustic impedance in this layer, which confirms the accumulation of hydrocarbons, as shown in Figure-10. 


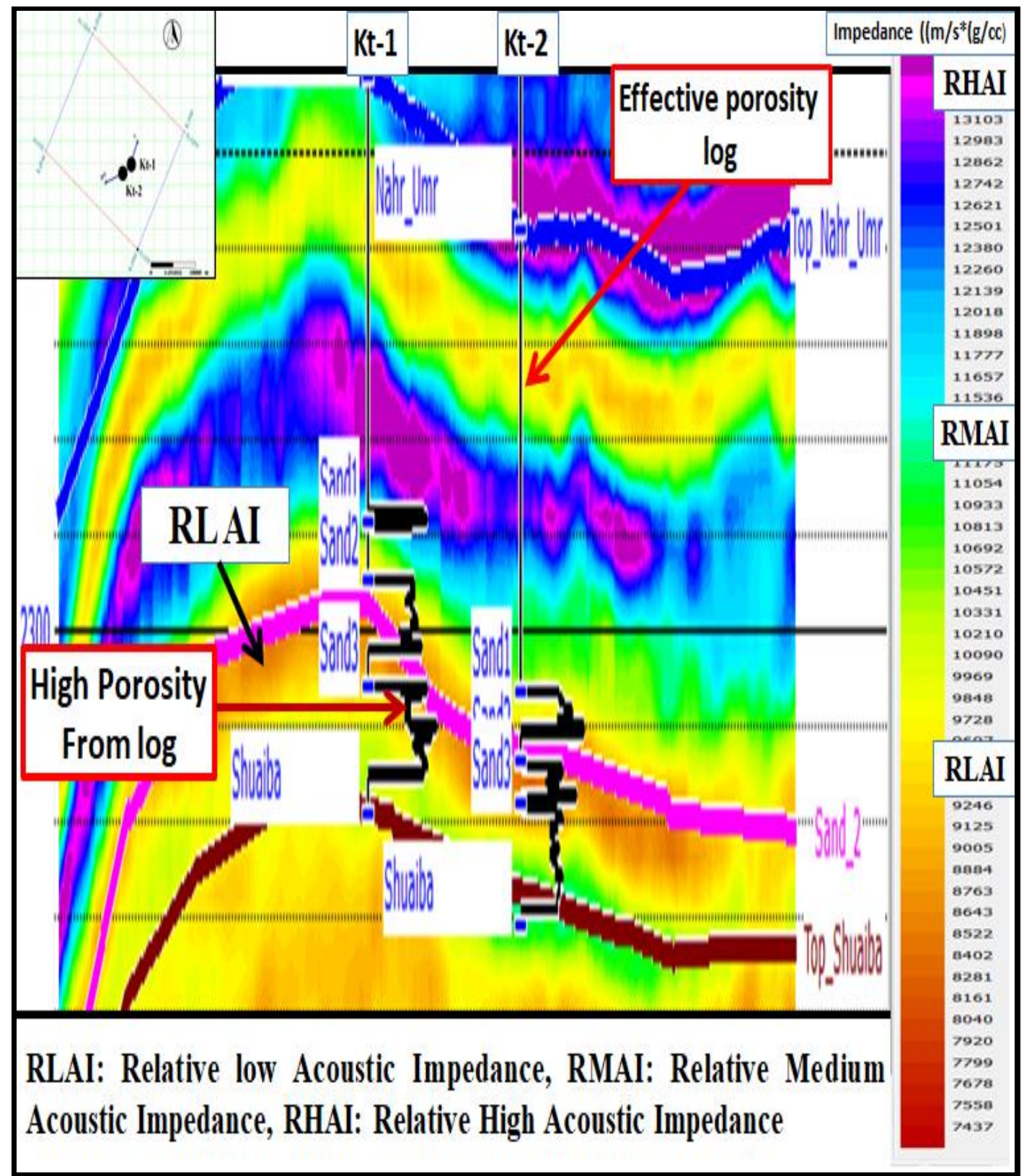

Figure10- Arbitrary section of inverted Relative Acoustic Impedance (RAI) with effective porosity logs in Nahr Umr Formation passing through wells Kt_1and Kt_2.

Figure-11 shows the acoustic impedance values for Nahr Umr Formation around Du-2 well, indicating relatively low acoustic impedance values with the increase of the porosity from log. The porous sand and shale attenuates the energy and low density contents decline the acoustic impedance values, the water reservoir proved in this layer. 


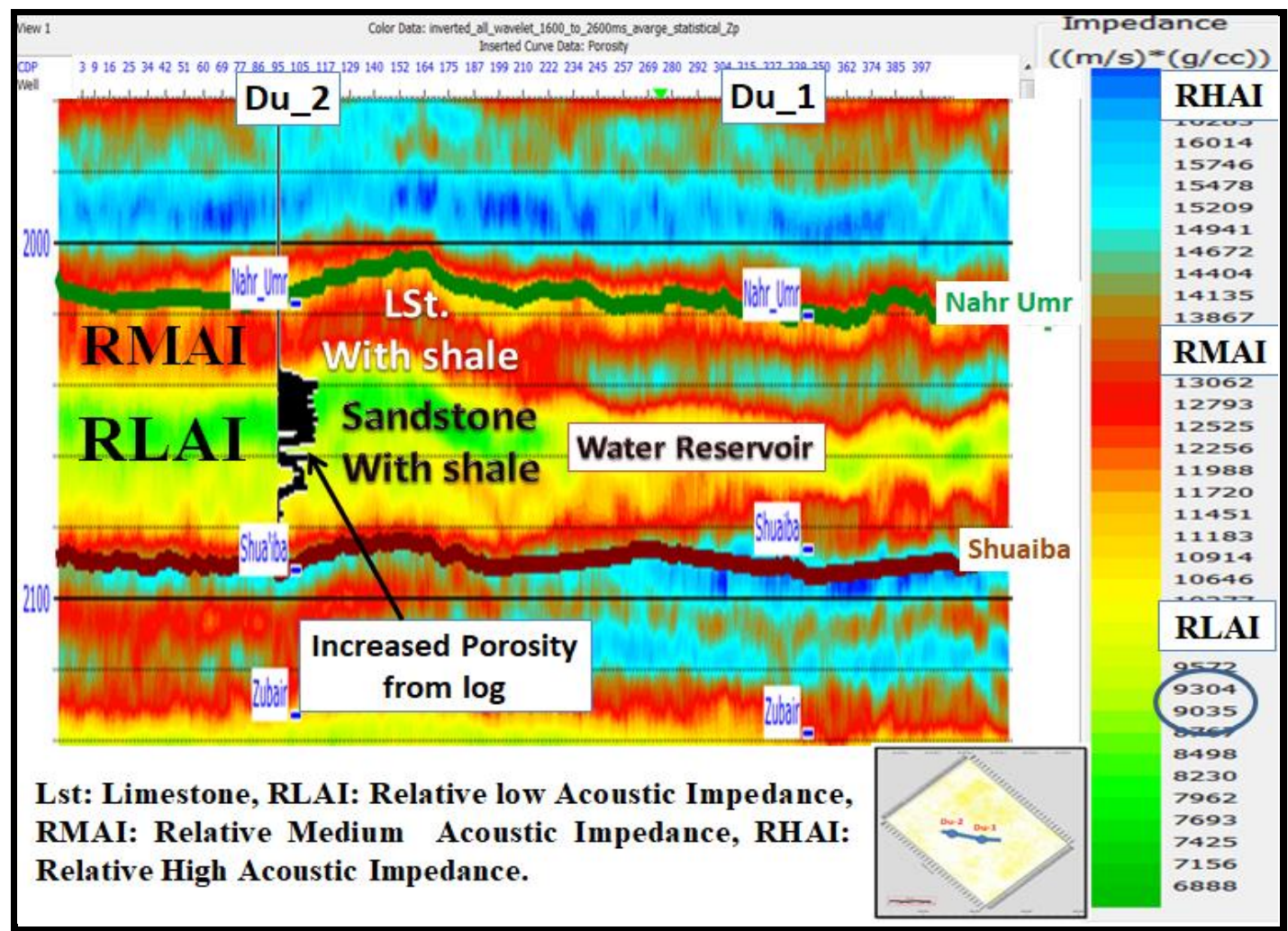

Figure 11- Arbitrary section of inverted Relative Acoustic Impedance (RAI) with effective porosity logs in Nahr Umr Formation passing through wells Du_1and Du_2.

The final results of the study are summarized in Table -2 .

Table 2- The results of well log analysis for reservoir characterization and acoustic impedance in Nahr Umr Formation

\begin{tabular}{|c|c|c|c|}
\hline $\begin{array}{c}\text { Physical and } \\
\text { Petro-physical } \\
\text { characterization }\end{array}$ & \multicolumn{2}{|c|}{$\begin{array}{c}\text { Sand-2 oil reservoir unit of Nahr Umr } \\
\text { Formation }\end{array}$} & $\begin{array}{c}\text { Water reservoir unit of } \\
\text { Nahr Umr } \\
\text { Formation }\end{array}$ \\
\cline { 2 - 4 } & Kt-1 & Kt-2 & Du-2 \\
\hline $\begin{array}{c}\text { Shale volume } \\
\text { (Vshale) }\end{array}$ & Low & low & high \\
\hline $\begin{array}{c}\text { Water Saturation } \\
\text { (Sw) }\end{array}$ & $\begin{array}{c}\text { Low in oil reservoir } \\
\text { High in oil-water } \\
\text { contact }\end{array}$ & high & medium \\
\hline Effective Porosity & medium & medium & Relatively low \\
\hline $\begin{array}{c}\text { Acoustic Impedance } \\
\text { (AI) }\end{array}$ & Relatively low & Relatively low \\
\hline
\end{tabular}

\section{Conclusions}

The reservoir properties of Kumait and Dujaila fields were examined through the relationships between the reservoirs and the acoustic effect. The seismic acoustic impedance inversion method and attribute analysis are considered as supportive methods to reservoir evaluation, based on the study of physical and petrophiycal properties of the rocks. The target reservoir intervals in Kumait field showed a hydrocarbon-bearing sand-2 unit in Nahr Umr Formation, which is identified by a relatively medium level of porosity with low values of shale volume and water saturation. The relatively low AI in this reservoir unit indicated hydrocarbon accumulation. Nahr Umr Formation in Dujaila field is distinguished by the presence of a water bearing unit in Du-2 well, which is reflected on petrophysical properties and AI values. This was achieved by comparing AI sections and well logs (shale volume, water saturation). The interpretation of seismic inversion sections showed variations in color, which is related to the change in lithology. Effective porosity can confer a new appearance to 
hydrocarbon accumulations. The authors recommend the use of such attribute to evaluate the reservoir content.

\section{References:}

1. Kumar et al, B. Das, R. Chatterjee, K. Sain, 2016.A methodology of porosity estimation from inversion of post stack seismic data. Journal of Natural Gas Science and Engineering, 28(January 01): 356-364. Article Download PDF Cross Ref View Record in Scopus Google Scholar. doi:10.1016/j.jngse.2015.12.028.

2. Nnaemeka Ezekwe., 2010. Petroleum Reservoir Engineering Practice: Porosity of Reservoir Rocks, Prentice Hall Publishing Company, pp 728-734

3. Hearst, J. R., Nelson, P.H., and Paillet, F.L., 2000. Well logging for physical properties, John Wiley \& Sons Ltd,. Chilchester., 411-439.

4. Dandekar, A. Y., 2006. Petroleum Reservoir Rock and Fluid Properties. Florida: CRC Press, Taylor \& Francis Group. 460 p. - ISBN 0-8493-3043-2.

5. Alwan, A.H., 2015. Evaluation Geological Study of Kumait Oil field. Geology and Geophysics in Oil Exploration, 39: p.17-20 Baghdad, DC, Iraq.

6. Jassim, S.M., 2013. Geological and geophysical study for 3D seismic survey in Dujaila Oil Field. Oil Exploration Company, 110: p.4-15 Baghdad, DC, Iraq.

7. Al-Ameri TK, Al-Ekabi AH and Al-Jawad SN 2014; Palynomorph stratigraphy, palynofacies and organic geochemistry assessments for hydrocarbon generation of Ratawi Formation, Iraq. Arab J Geosci, 7(4): 1433-1455.

8. Getech and Jassim, S, Z., 1998. North Araabia basement morphology study: Integrated geological, geophysical and hydrocarbon potential study, GETECH, School of Earth Sciences, University of Leeds, England, Report no,G904,219p.

9. Al-Khadhimi, J.A., Sissakian, V.K., Fatah, A.S., and Deikran, D.B., 1996. Tectonic map of Iraq (Scale 1: 1000000) S.E of Geological Survey and Mining, Iraq.

10. Al-Banna A.S., Daim F. M. and Al-Zubaidi A.M. , 2017. The deep faults in Kut-Hai and surrounding area inferred from gravity and magnetic data. Iraqi J. Sci. 58(3A): 1235-1245.

11. Al-Banna A. S. Al-Zubaidi A.M. and Daim F. M. 2017, The oil fields relation to tectonic boundaries that inferred from seismic and gravity interpretation in Kut -Hai- Fajir and surrounding area, central Iraq. Iraqi J. Sci.: 58(4A): 1910-1917.

12. Al-Banna A. S. and Daham A. N. 2019. Tectonic boundaries and depth estimation of some gravity sources in Diyala area, east central Iraq. Iraqi J. Sci.: 60(2): 308-320.

13. Al- Banna A. S. and Al-Namar A. F. 2019. Gravity and magnetic interpretation to study crustal structures in Karabala and surrounding areas, central Iraq. Iraqi J. Sci.: 60(3): 536-544.

14. Russell, B., Hampson, D., 2006. "The Old and the New in Seismic Inversion", CSEG Recorder, December, pp. 5-11.

15. Dean, Lisa. 2007. Reservoir Engineering for Geologists: Part 3-Volumetric Estimation Reservoir, Canadian Society of Petroleum Geologists. 11: pp. 20-23.

16. Larionov, V.V. 1969. Borehole Radiometry Moscow, U.S.S.R. In: Nedra, M.R.L. and Biggs, W.P., Eds., Using Log-Derived Values of Water Saturation and Porosity, Trans. SPWLA Ann. Logging Symp. Paper, 10, 26.

17. Asquith, G. B., Krygowski, D. and Gibson, C. R. 2004.Basic well log analysis, :16. Tulsa: American Association of Petroleum Geologists.

18. Hamada, G.M. 2008. Accuracy analysis of water saturation models in clean and shale layers. In: SPE Saudi Arabia Section Technical Symposium, 10-12 May 2008, Al-Khobar, Saudi Arabia, Paper SPE 120809.

19. Archie, G.E. 1942.The Electrical Resistivity Log as an Aid in Determining Some Reservoir Characteristics. Trans of AIME, 146(1): 54-62. http://dx.doi.org/10.2118/942054-G.

20. Al-Ruwaili, S.A. and Al-Waheed, H.H. 2004. "Improved Petrophysical Methods and Techniques for Shaly Sands Evaluation," paper SPE 89735 presented at the 2004 SPE International Petroleum Conference in Puebla, Mexico, November 8-9, 2004. 